\title{
Legal Corporate Insider Trading and the Price Impact of Private Information: Evidence for Germany
}

\author{
Wolfgang Aussenegg* and Robert Ranzi
}

\author{
Department of Finance and Corporate Control, Vienna University of Technology, Favoritenstrasse 9-11, A-1040 \\ Vienna, Austria
}

\begin{abstract}
This study examines the information value of corporate insider trading disclosures for a sample of 490 German companies. Our results indicate that insiders selling stocks in their own company reveal negative information about the intrinsic firm value. This is especially the case for large volume sale transactions. In addition, stock prices of smaller companies react stronger to insider transactions. Furthermore, insiders tend to time their transactions, selling shares after stock price increases and buying shares after stock price decreases.
\end{abstract}

Keywords: Corporate insider trading, event study, abnormal performance, German stock market.

\section{INTRODUCTION}

Insider trading occurs when corporate insiders, like, e.g. managers or members of the supervisory board buy or sell stocks of their own company. The trading activities of these insiders are not forbidden, however, the use of insider knowledge in such transactions is illegal. To protect the public and to improve market transparency, the disclosure of corporate insider trading is an important aspect in a modern financial system. The disclosure of insider trading has therefore been required in the U.S. since 1934 and in the U.K. since 1976.

Compared with this, in continental Europe such regulatory needs became effective only within the last five to ten years. Under the EU 'market abuse' directive EU member states are forced to implement local regulations that require the disclosure of corporate insider trading till October, $12^{\text {th }}$ 2004. ${ }^{1}$ In Germany the corresponding regulation came already into force on July, $1^{\text {st }} 2002$. $\$ 15$ a of the Securities Trading Act requires corporate insiders to disclose their trades within five trading days after the buying or selling activity took place. This delay of up to five trading days is, e.g., comparable with the current regulation in the U.S. Since August 2002, according to Section 403(a) of the SarbanesOxley Act of 2002, insiders in the U.S. are required to report their transactions within two trading days following the day on which the transaction has been executed. ${ }^{2}$

*Address correspondence to this author at the Department of Finance and Corporate Control, Vienna University of Technology, Favoritenstrasse 9-11, A-1040 Vienna, Austria; Tel: +43 158801 33082; Fax: +43 158801 33098; E-mail: waussen@pop.tuwien.ac.at

\footnotetext{
${ }^{1}$ Directive 2003/6/EC of the European Parliament and of the Council of 28 January 2003 on insider dealing and market manipulation (market abuse). Article 18 of this Directive requires member states to assemble the Directive not later than October, $12^{\text {th }} 2004$.

${ }^{2}$ It is important to note that till July 2002 the delay between insider transaction and disclosure has been much longer in the U.S. According to Section 16(a) of the Securities and Exchange Act of 1934, insiders were required to report their transactions by the tenth day of the calendar month after the trading month. E.g., Aktas et al. [6] report for their sample of U.S. insider deals an average delay of 22 days.
}

Many empirical studies on insider trading activities document that insiders (and to some extend also outsiders that follow insider transactions) are able to earn significant abnormal returns during the first weeks or even month after trading. This is true for early (see, e.g., Jaffe [1], Finnerty [2], or Seyhun [3]) and also recent U.S. studies (like, e.g., Lakonishok and Lee [4], Jeng et al. [5], or Aktas et al. [6]). Comparable results are also documented for some European markets, like the UK (see, e.g., Pope et al. [7], Gregory et al. [8], and more recently Calvo and Lasfer [9], or Fidrmuc et al. [10]), the Netherlands (see Biesta et al. [11] and Aktas et al. [12]), or Spain (see Del Brio et al. [13]). Eckbo and Smith [14] report zero or even negative abnormal returns for insider transaction in Norway.

The aim of this study is to examine the information value of corporate insider trading disclosure for a sample of 490 German companies with 7,762 legal insider transactions. If a company immediately passes on all pricing-relevant information, company outsiders should not attribute importance to announcements of insider trading activities. On the other hand, if company outsiders feel that they are not fully informed by corporate management, insider trading actions by managers is supposed to reveal additional information about the management's assessment of the actual firm value.

In Germany, laws forcing insiders to disclosure their trading activities came into effect only on July $1^{\text {st }}, 2002$. Previously, only a non binding gentlemen's agreement urged insiders to disclose their trading activities. Therefore, our investigation period starts on July $1^{\text {st }}, 2002$ and lasts until December $12^{\text {th }}, 2007$. We add to the vast literature on insider trading an analysis of the impact of recent EU-law and amplify our understanding of market reaction for the German stock market.

Our main findings so far are first, that insiders that buy stocks in their own company reveal positive information about the intrinsic firm value. Second, selling transactions also seem to contain pricing relevant information contrary to the findings for market reaction to insider trading in the U.S. Third, we document that stock prices of smaller firms react 
stronger to insider trading disclosures compared to stock prices of larger firms. Fourth, we show that large volume trades reveal more information about firm value than small volume trades do.

Our research adds to the literature in the following ways. First, we concentrate on insider trading in Germany, thus deepening the understanding of the effects of insider trading outside the U.S. Laws obligating corporate insiders to disclose trading came into effect only in 2002 following an EU directive. It might be of interest how market participants react to the disclosure of insider trading and whether or not market participants changed their perception of information contained in such disclosures.

Second, we analyze the efficiency of corporate information policy. Granted that a company's information policy is efficient, the disclosure of insider transactions should not cause significant price changes.

The remainder of the paper is organized as follows. Section 2 reviews the relevant literature on insider trading disclosure. Section 3 describes the used sample and in section 4 we explain our research design. Section 5 presents the empirical results and concluding remarks are set out in Section 6.

\section{LITERATURE REVIEW}

Previous studies on insider trading highlight the ability of corporate insiders to predict the cross-sectional variation of future stock returns. Beginning with Lorie and Niederhoffer [15] and Jaffe [1], academics focused on how informative insider trades are. A typical research design consists of the definition of a trading rule relying for example on the number of shares bought or sold by insiders during a month. Purchase and sale portfolios are then created according to the specified trading rule. All these studies conclude nearly unanimously that purchase portfolios outperform relevant benchmarks, whereas results for sale portfolios are not that explicit. The lack of significant negative abnormal returns after insider sales is commonly attributed to increased legal risk associated with insider sales before a drop in share price.

Another approach was implemented by Jeng et al. [5]. The authors focus on the estimation of the returns earned by insiders. They construct purchase and sale portfolios directly based on the insiders' decisions and report abnormal returns of 50 basis points per month for the purchase portfolio whereas the sale portfolio does not earn abnormal profits.

Studies by other authors focus on trading strategies implemented by insiders. It is noteworthy that insiders are unmasked as contrarian investors - a hint that they might base their trading decisions upon private information. Kose and Lang [16] provide evidence of insiders strategically buying shares around dividend announcements. Huddart et al. [17] present an insider's equilibrium trading strategy in a multiperiod rational expectations framework. They offer dissimulation as an explanation for contrarian trading by insiders maximizing profits. Piotroski and Roulstone [18] investigate the extent to which the trading by corporate insiders influences the information impounded into stock prices.

Aktas et al. [6] analyse the connection between information content of legal insider trading and market efficiency. In using a sample of 59,244 insider transactions in 2,110 com- panies listed on the New York Stock Exchange Aktas et al. [6] provide an indication that insider trading activity accelerates price discovery. In a recent study Jiang and Zaman [19] decompose realized market returns to test whether insiders act as contrarian investors or whether they time their trades. Their findings indicate that insiders time the market because of their superior knowledge about the company.

However, the vast majority of previous work focused on U.S. capital markets and sparse research was done on insider trading in other countries. Wong et al. [20] use an event study approach to analyze insider trading and market efficiency on the Hong Kong stock exchange. Del Brio et al. [13] investigate the profitability of insider trading in the Spanish stock market. Their results suggest that insiders earn excess profits, while outsiders mimicking them fail to obtain positive excess returns.

Aktas et al. [12] analyze legal insider trading on the Euronext Amsterdam stock exchange. The authors adopt a betaone model to assess the market's reaction to the disclosure of insider transactions and find only in the long run (i.e. 200 trading days) significant price changes following insider transactions.

Research on insider trading in Germany started mainly after the implementation of the new insider trading disclosure regulation in July 2002. Heidorn et al. [21] consider insider legislation in Italy, Germany and in the Netherlands. For Germany, they limit themselves on insider trades between July 2002 and March 2004. Their conclusions are consistent with the findings in prior research on insider transactions in the U.S., namely the contrarian nature of insider transactions, significant abnormal returns after insider purchases and the lack of significant abnormal returns after sale transactions.

The research sample used by Stotz [22] covers the first year following implementation of the new insider law in July 2002. He finds evidence of significant positive abnormal returns after insider purchases and negative abnormal returns after insider sales.

For a two year sample of 2,522 insider transactions Betzer and Theissen [23] show that insider deals are associated with significant abnormal returns. This is especially the case for deals that took place prior to earnings announcements, when the informational asymmetry between insiders and outsiders tends to be highest. To protect minority shareholders it might therefore be a good advice to prohibit insiders from trading before earnings announcement, as it is, e.g. already the case in the UK.

Dymke and Walter [24] relate insider transactions to adhoc news disclosures. They document for a sample of 3,079 German deals that insiders trade on inside information. Most active in exploiting inside information are supervisory board members. They tend to realize high profits with their frequent front-running transactions.

Klinge et al. [25] are using German data for the two year period following the introduction of the new insider disclosure regulation in July 2002. They show that, as in the U.S. and the UK, abnormal returns tend to be negative (positive) on the days before insider purchase (sales), and positive (negative) on the transaction day and the following days. This effect is much 
more pronounced around sales. From their cross-sectional regressions they conclude that diversification and liquidity motives as well as price pressure effects are the main reasons for the abnormal return patterns in their sample.

\section{DATA}

\subsection{Insider Transactions}

Our research focuses on the period beginning on July $2^{\text {nd }}$, 2002 and ending on December $12^{\text {th }}$, 2007. Starting with July $2^{\text {nd }}, 2002, \S 15$ a of the German Securities Trading Act oblige corporate insiders to disclose their transactions in securities of their firm. By law, corporate insiders are members of the management board and members of the supervisory board as well as individuals with access to insider information. The obligation to disclose insider transactions also holds for firstdegree relatives and marriage partners.

The German Law forces insiders to communicate their trading activities in electronic form. These disclosures are then published on various websites, e.g. the site of the Fed- double counting of insider trades. We further remove announcements that contain obvious errors, like having the day of disclosure before the day of trading.

In addition, we aggregate all purchase (sale) deals of the same insider that took place on the same trading day. Such trading patterns might be due to partial execution of orders and do not convey additional information. However, in contrast to other authors (e.g. for Germany Betzer and Theissen [23]) we do not aggregate purchases and sales by different insiders in the same security on the same trading day. In our view there is a difference between one insider buying (selling) and more insiders buying (selling) on a specific date: if more insiders buy (sell) this conveys more information than if only one insider trades. We limit our study on insiders buying or selling shares of their company - thus we ignore all transactions in other securities like derivatives and equity funds.

In total this leads to a database containing 3,877 buy and 3,885 sell transactions for corporate insiders in Germany from July $2^{\text {nd }}, 2002$ until December $12^{\text {th }}, 2007$ (see Table 1).

Table 1. Sample Selection Process

\begin{tabular}{|c|c|c|}
\hline & Insider Purchase Transactions & Insider Sale Transactions \\
\hline Downloaded sample & 11,420 & 8,664 \\
\hline $\begin{array}{l}\text { Obvious double counting in the database (if transactions in a security executed by the } \\
\text { same insider on the same day with similar amount and price are found in the database, } \\
\text { only one is counted), and obvious errors (e.g. when the disclosure date is before the day } \\
\text { of trading) }\end{array}$ & $-2,531$ & $-1,390$ \\
\hline Remaining Data & 8,889 & 7,274 \\
\hline $\begin{array}{l}\text { Because we are interested in the announcement effects of legal insider trading we aggre- } \\
\text { gate disclosures of an insider made on the same day concerning the same financial } \\
\text { security }\end{array}$ & $-3,199$ & $-1,986$ \\
\hline Remaining Data & 5,690 & 5,288 \\
\hline $\begin{array}{l}\text { We focus on shares; therefore, we eliminate transactions in other securities (e.g. options, } \\
\text { investment funds) }\end{array}$ & $-1,813$ & $-1,403$ \\
\hline Remaining Data & 3,877 & 3,885 \\
\hline
\end{tabular}

This table delineates the sample selection process. We use two different data sources to create our sample. Consequently we have to scrutinize the data sets to avoid double counting. Hereafter we aggregate the remaining transactions.

eral Financial Supervisory Authority (BaFin; www.bafin.de). We use this online database as well as other resources on the web to download insider disclosures ${ }^{3}$. All disclosures are formatted in the same way and group the information content into two blocks. The first block contains the ISIN (International Securities Identification Number) of the company, the firm name, the name of the insider, and her/his position in the company. The second block of information contains trading specific data, like the date of the insider trade, the disclosure date, the transaction type (purchase or sale), the number of shares traded, the price of buying or selling the shares, and the transaction volume (in Euro).

\subsection{Descriptive Statistics}

Our initial dataset contains 11,420 insider purchase transactions and 8,664 insider sales transactions. Due to the fact that we use multiple data sources we have to control for

${ }^{3}$ These other resources include the financial information websites www.finanzen.net and www.ariva.de
Purchases take place in 421 and sales in 391 companies. Fig. (1) reveals that the number of insider transactions increased over time.

The average number of declared buy transactions per company is 9.21 and for sell transactions 9.94 , whereas the average buy transaction volume is EUR 1,772,682 (median: EUR 40,800) and the average sell transaction volume is EUR 2,780,450 (median: EUR 106,319). The overall volume is EUR 6,872.7 Mio for buy transactions and EUR 10,802.1 million for sell transactions (see Table 2). The fact that the volume of sell transactions exceeds the volume of buy transactions is consistent with findings in prior research and provides evidence of performance-related managerial remuneration like stocks and stock options.

Where available, we gather stock quotes from Reuters. Altogether, we have daily quotes of 490 companies where insider trading occurred in the research period (July 2002 December 2007). Daily stock returns are calculated by taking 


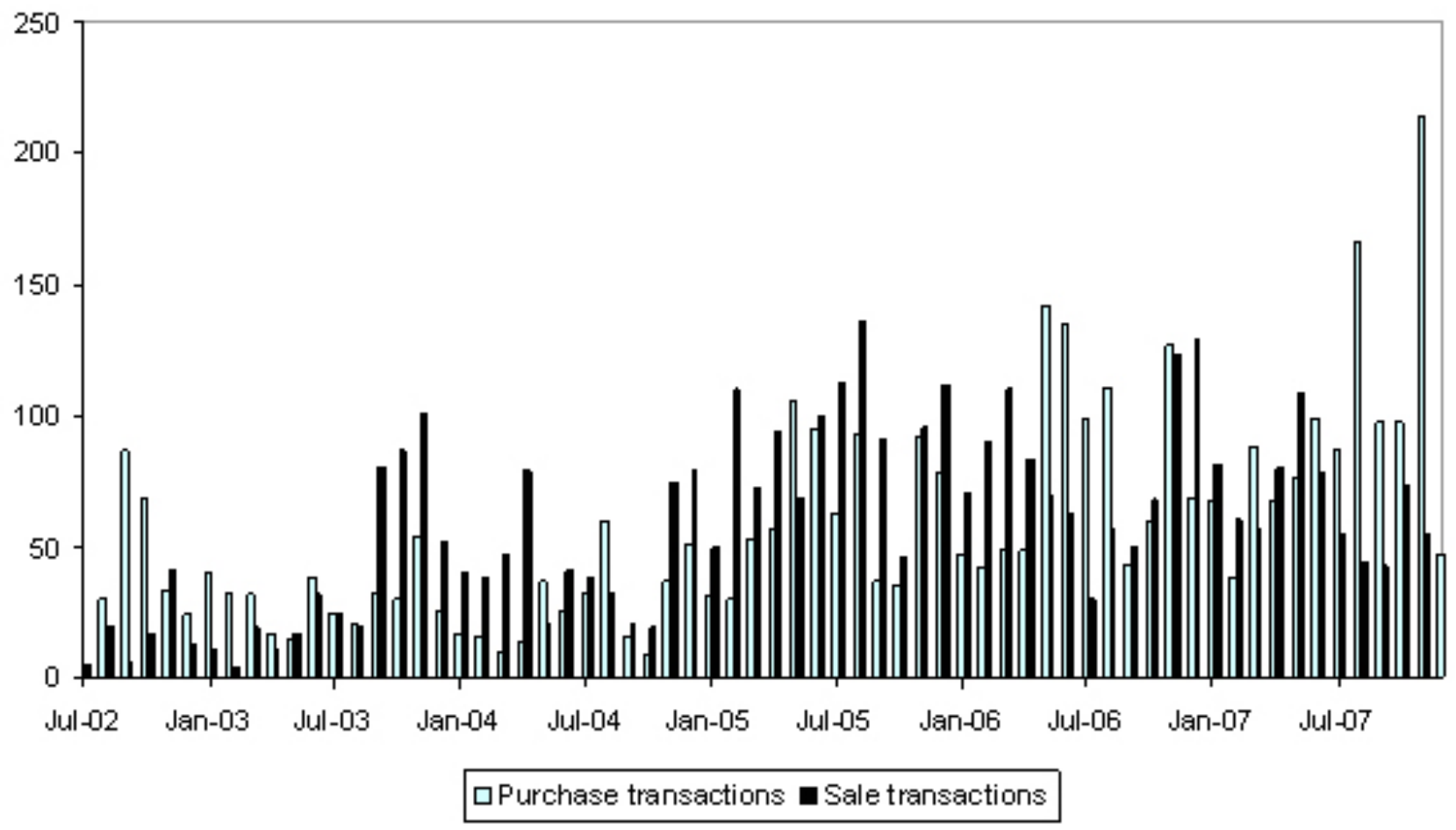

Fig. (1). Number of insider transactions. Number of insider purchase and insider sale transactions per month (July 2002 until December 2007).

Table 2. Descriptive Statistics

\begin{tabular}{|c|c|c|c|c|c|c|}
\hline \multirow{2}{*}{ Transactions } & \multirow{2}{*}{ Number of Firms } & \multirow{2}{*}{ Number of Disclosures } & \multicolumn{2}{|c|}{ Volume Per Disclosure } & \multirow{2}{*}{$\begin{array}{c}\text { Total Volume in } \\
\text { Million } €\end{array}$} & \multirow{2}{*}{$\begin{array}{c}\text { Ratio } \\
\text { \# of Disclosures } \\
\text { \# of Companies }\end{array}$} \\
\hline & & & Mean in $€$ & Median in $€$ & & \\
\hline Purchases & 421 & 3,877 & $1,772,682$ & 40,800 & $6,872.7$ & 9.21 \\
\hline Sales & 391 & 3,885 & $2,780,450$ & 106,319 & $10,802.1$ & 9.94 \\
\hline Total & 490 & 7,762 & $2,277,085$ & 60,490 & $17,674.7$ & 15.84 \\
\hline
\end{tabular}

This table shows descriptive statistics for the total sample of 7,762 corporate insider transactions for the entire investigation period from July 2002 until December 2007.

into account dividend payments and corporate actions, like stock splits or SEOs.

We evaluate the information effects of insider trading disclosures with various sub samples. To calculate the market reaction for small and large companies, groups of small and large companies are constructed as follows. On the first trading day of each year the median of the market value of all the 490 companies is calculated. Then the market value of the company of each disclosure is compared to the relevant year's median of market values.

We construct another sub-sample to evaluate whether the transaction size has an impact on the price performance. We define purchase (sale) transactions as large transaction if the transaction volume is greater than the median transaction volume of all purchases (sales). Small purchase and sales transactions are defined correspondingly.

To calculate market adjusted returns the CDAX index (ISIN DE0008469602) is used as a proxy for the market portfolio. CDAX is calculated by the Frankfurt Stock Ex- change and is a performance index. This means that all payments to the shareholders of the index' constituents are supposed to be reinvested in the corresponding company.

\section{RESEARCH DESIGN}

\subsection{Methodology}

To measure the price effects of legal insider trading disclosures we adopt an event-study design. Even though eventstudy like research design has been applied since the early nineteen-thirties (MacKinlay [26] mentions research done by Dolley in 1933 about the price effects of stock splits), only after the seminal papers of Ball and Brown [27] and Fama et al. [28] the event-study methodology attained a larger diffusion among the academic community. But since then, academics and practitioners produced many event studies in nearly every field of economics ranging from seasoned equity offers to the effects on firm value of a change in the regulatory environment (see MacKinlay [26]). Usually, event studies use financial data to measure the effects of an event on the value of a firm. Granted that market participants are 
rational, they will react to the event and their reaction will make the security's price change. We apply the common event study approach and design delineated in MacKinlay [26] and in Campbell et al. [29].

In this analysis we focus on short-term effects of disclosures of legal insider transactions. There should not be any price reaction observable unless either market participants assess insider disclosures contain information not yet issued by the company and therefore not yet incorporated into stock prices or insiders are able to time their transactions.

\subsection{Event Definition}

Following Campbell et al. [29] we use 120 trading days to estimate the market model parameters. ${ }^{4}$ In order to get a better understanding of the price dynamics around the disclosure date, we use multiple event windows. The event we analyze is the disclosure of insider transactions and the corresponding disclosure day is labeled as $\mathrm{T}_{0}$ for every event. The research period is measured in trading days, therefore $T_{1}$ denotes the first trading day after the event, $\mathrm{T}_{2}$ denotes the second trading day after the event and so forth.

In a first step, we investigate the 20, 10 and 5 trading day intervals before the insider trading disclosure to grasp the evolution of the security's price before the announcement. The price movements in these intervals may include valuable information for the analysis because the price movements by themselves might persuade the insiders to trade. In addition, we analyze the 5, 10 and 20 trading days following the disclosure date - that is one, two and four trading weeks after $\mathrm{T}_{0}$. This analysis enables us to assess the market's reaction to the disclosure of insider transactions.

\subsection{Abnormal Returns}

To measure the effect of insider trading disclosures on market prices we calculate abnormal returns for the respective securities. Ex-post abnormal returns are calculated as the difference between returns of the relevant company and the return one would expect without the event.

$\mathrm{r}_{\mathrm{it}}=\mathrm{E}\left[\mathrm{r}_{\mathrm{it}}\right]+\varepsilon_{\mathrm{it}}$

where $r_{i t}$ is the observed return of stock $i$ on day $t, E[$.$] the$ expectation value operator and $\varepsilon_{\text {it }}$ represents the abnormal return of company $i$ on day $t$.

In rearranging (1) we get a direct measure for the abnormal return:

$\varepsilon_{\text {it }}=r_{\text {it }}-E\left[r_{i t}\right]$

For every day of the event period we calculate the average abnormal return of all stocks that experience the event. The abnormal return (AR) for trading day $t$ is calculate as follows:

$A R_{t}=\frac{1}{N} \sum_{i=1}^{N} \varepsilon_{i t}$

By cumulating the one-day AR from (3) over a particular time interval we obtain the cumulative abnormal return

${ }^{4}$ To be comparable with most parts of the literature concerning insider trading we are using a 120 trading day estimation window. Our main results and conclusions do not change when we decrease the estimation window to 60 trading days.
(CAR). The CAR for a specific period is calculated as the sum of all AR between $\tau_{1}$ and $\tau_{2}$.

$$
C A R_{\tau_{1}, \tau_{2}}=\sum_{t=\tau_{1}}^{\tau_{2}} A R_{t}
$$

To estimate normal returns we use the market model approach. The market model for security $i$ and observation $t$ is

$r_{i t}=\alpha_{i}+\beta_{i} \cdot r_{m t}+\varepsilon_{i t}$,

where $r_{m t}$ represents the return of the market portfolio (in our case the CDAX index) for trading day t. A linear OLS regression and a 120 trading day estimation window prior to the event window is used to estimate the model parameters $\alpha_{i}$ and $\beta_{\mathrm{i}}$. Subsequently, abnormal returns are calculated using financial market data observed during the event window. The abnormal return vector is calculated as follows:

$\varepsilon_{i}=R_{i}^{*}-\hat{\alpha}_{i} l-\hat{\beta}_{i} R_{m}^{*}$,

where $R_{i}^{*}$ is a vector of event window security returns, $\boldsymbol{l}$ is a vector of ones, $R_{m}^{*}$ is a vector of event window market returns, and $\hat{\alpha}_{i}$ and $\hat{\beta}_{i}$ represent model parameter estimates.

\subsection{Significance of Abnormal Returns}

We perform three types of statistical tests to examine the significance of abnormal returns. The first test is a parametric test as proposed by Campbell et al. [29] and MacKinlay [26]. The test-statistic is defined as follows:

$$
\theta=\frac{\operatorname{CAR}\left(\tau_{1}, \tau_{2}\right)}{\sqrt{\operatorname{var}\left(C A R\left(\tau_{1}, \tau_{2}\right)\right)}}
$$

The cumulative abnormal return between two dates $\tau_{1}$ and $\tau_{2}\left(\operatorname{CAR}\left(\tau_{1}, \tau_{2}\right)\right)$ is calculated as described above and $\operatorname{var}\left(\operatorname{CAR}\left(\tau_{1}, \tau_{2}\right)\right)$ is the variance of the cumulative abnormal returns. For large samples $\theta$ can be considered to be asymptotically $\mathrm{N}(0,1)$-distributed.

Parametric tests assume that individual firm's abnormal returns are normally distributed - whereas the literature suggests that abnormal returns in event studies are, sometimes heavily, skewed. For this reason we perform two other tests, namely a Wilcoxon signed rank test and a proportion test. These two tests start with a similar hypothesis: they both assume that positive or negative abnormal returns are equally probable. Consequently, their test results show the same sign.

The Wilcoxon signed rank test examines whether or not abnormal returns occur (i.e. whether the median is significantly different from zero). The Wilcoxon signed rank statistic $W_{+}$is defined as follows: ${ }^{6}$

$W_{+}=\sum_{i=1}^{N} r^{+}$

In equation (8) $r^{+}$is the positive rank of the absolute value of cumulative abnormal returns. For large samples $W_{+}$ will be approximately normally distributed.

\footnotetext{
${ }^{5}$ See MacKinlay [26] and Campbell et al. [29] pp. 160 et sqq. ${ }^{6}$ See, e.g. Serra [30].
} 
The proportion test investigates whether the proportion (P) of events with positive CARs differs from $50 \% .^{7}$ Under the null hypothesis of exactly $50 \%$ positive CARs the expectation of the proportion $E[P]$ is 0.5 :

$$
E[P]=\theta=0.5,
$$

and its variance is:

$\operatorname{VAR}(P)=\sigma_{P}^{2}=\frac{\theta(1-\theta)}{N}$.

Standardizing P leads to:

$$
Z=\frac{P-\theta}{\sigma_{P}}=\frac{P-\theta}{\sqrt{\frac{\theta(1-\theta)}{N}}}
$$

The test statistic $\mathrm{Z}$ is standard normal distributed. level) for the last twenty trading days before the announcement (see Table 3). In contrast to findings for the U.S. prices decline significantly after the announcement of insider transactions. Strictly speaking, prices start to decline 3-4 days before the announcement, i.e. after the transaction itself. This is an interesting point, because it implies that either the insiders' transactions cause the security prices to decline or market participants learn about the insiders' transactions before the official disclosure and react to this information or market participants react to other information disclosures in the days between the insider transaction and its disclosure.

After the disclosure of insiders' selling activities prices decline almost linearly: the CAR for $\mathrm{T}_{0}-\mathrm{T}_{5}$ is $-0.98 \%$, for $\mathrm{T}_{0^{-}}$ $\mathrm{T}_{10}-1.69 \%$ and for $\mathrm{T}_{0}-\mathrm{T}_{20}-3.18 \%$ (all statistically significant different at the $1 \%$ level). The fact that security prices decline after insider sale transactions in Germany implies that corporate insiders do not fear the legal hazard inherent

\begin{tabular}{|c|c|c|c|c|c|c|}
\hline & \multicolumn{3}{|c|}{ Insider Purchase Transactions } & \multicolumn{3}{|c|}{ Insider Sale Transactions } \\
\hline & Mean $(\%)$ & Median (\%) & Proportion of positive CAR (\%) & $\operatorname{Mean}(\%)$ & Median (\%) & Proportion of positive CAR (\%) \\
\hline \multirow{3}{*}{$\mathrm{T}_{-20}-\mathrm{T}_{-1}$} & -2.20 & -2.17 & 39.67 & 2.93 & 1.05 & 54.03 \\
\hline & $(9.06)$ & {$[0.000]$} & $(-12.86)$ & (11.03) & {$[0.000]$} & $(5.02)$ \\
\hline & {$[0.000]$} & & {$[0.000]$} & {$[0.000]$} & & {$[0.000]$} \\
\hline \multirow{3}{*}{$\mathrm{T}_{-10}-\mathrm{T}_{-1}$} & -1.23 & -1.22 & 41.71 & 1.51 & 0.37 & 52.05 \\
\hline & $(7.44)$ & {$[0.000]$} & $(-10.33)$ & $(8.33)$ & {$[0.000]$} & $(2.55)$ \\
\hline & {$[0.000]$} & & {$[0.000]$} & {$[0.000]$} & & {$[0.005]$} \\
\hline \multirow{3}{*}{$\mathrm{T}_{-5}-\mathrm{T}_{-1}$} & -0.46 & -0.71 & 42.79 & 0.51 & -0.12 & 48.49 \\
\hline & $(3.99)$ & {$[0.000]$} & $(-8.98)$ & $(4.09)$ & {$[0.496]$} & $(-1.88)$ \\
\hline & {$[0.000]$} & & {$[0.000]$} & {$[0.000]$} & & {$[0.030]$} \\
\hline \multirow{3}{*}{$\mathrm{T}_{0}-\mathrm{T}_{5}$} & 0.54 & 0.06 & 50.71 & -0.98 & -0.93 & 38.64 \\
\hline & $(4.74)$ & {$[0.003]$} & $(0.88)$ & $(7.84)$ & {$[0.000]$} & $(-14.17)$ \\
\hline & {$[0.000]$} & & [0.189] & [0.000] & & {$[0.000]$} \\
\hline \multirow{3}{*}{$\mathrm{T}_{0}-\mathrm{T}_{10}$} & 0.75 & 0.18 & 51.38 & -1.69 & -1.47 & 38.76 \\
\hline & $(4.52)$ & {$[0.001]$} & $(1.72)$ & $(9.36)$ & {$[0.000]$} & $(-14.01)$ \\
\hline & {$[0.000]$} & & {$[0.043]$} & {$[0.000]$} & & {$[0.000]$} \\
\hline \multirow{3}{*}{$\mathrm{T}_{0}-\mathrm{T}_{20}$} & 0.85 & 0.31 & 51.38 & -3.18 & -2.74 & 35.44 \\
\hline & $(3.51)$ & [0.009] & $(1.72)$ & (11.98) & {$[0.000]$} & $(-18.15)$ \\
\hline & {$[0.000]$} & & [0.043] & {$[0.000]$} & & [0.000] \\
\hline
\end{tabular}

Table 3. Abnormal Performance of Insider Trades Around the Disclosure Date

Mean and median cumulative abnormal returns (CARs) and the proportion of positive CARs for the total sample of insider purchase and sale transactions over the entire sample period from July 2002 until December 2007. Test statistics are given in brackets () and p-values within [].

\section{EMPIRICAL RESULTS}

\subsection{General Results}

Consistent with the findings in previous research insiders in Germany emerge as contrarian investors. They tend to sell securities after periods of high abnormal returns. For the total sample of 3,855 insider sale transactions the average CAR is $+2.93 \%$ (significantly different from zero at the $1 \%$

\footnotetext{
${ }^{7}$ See, e.g., Serra [30].
}

in insider trading based on private information about unfavorable development of the company. The insiders' attitude is possibly driven by the absence of class-action lawsuits under German law.

On the other hand, insiders tend to buy stocks of their companies after periods of negative abnormal returns. For the period $\mathrm{T}_{-20}-\mathrm{T}_{-1}$, that is the twenty days before the insider transaction disclosure we detect an average CAR of $-2.2 \%$. After the disclosure of insider purchase transactions a positive CAR of $+0.85 \%$ for $\mathrm{T}_{0}-\mathrm{T}_{20}$ is observable, however, its 


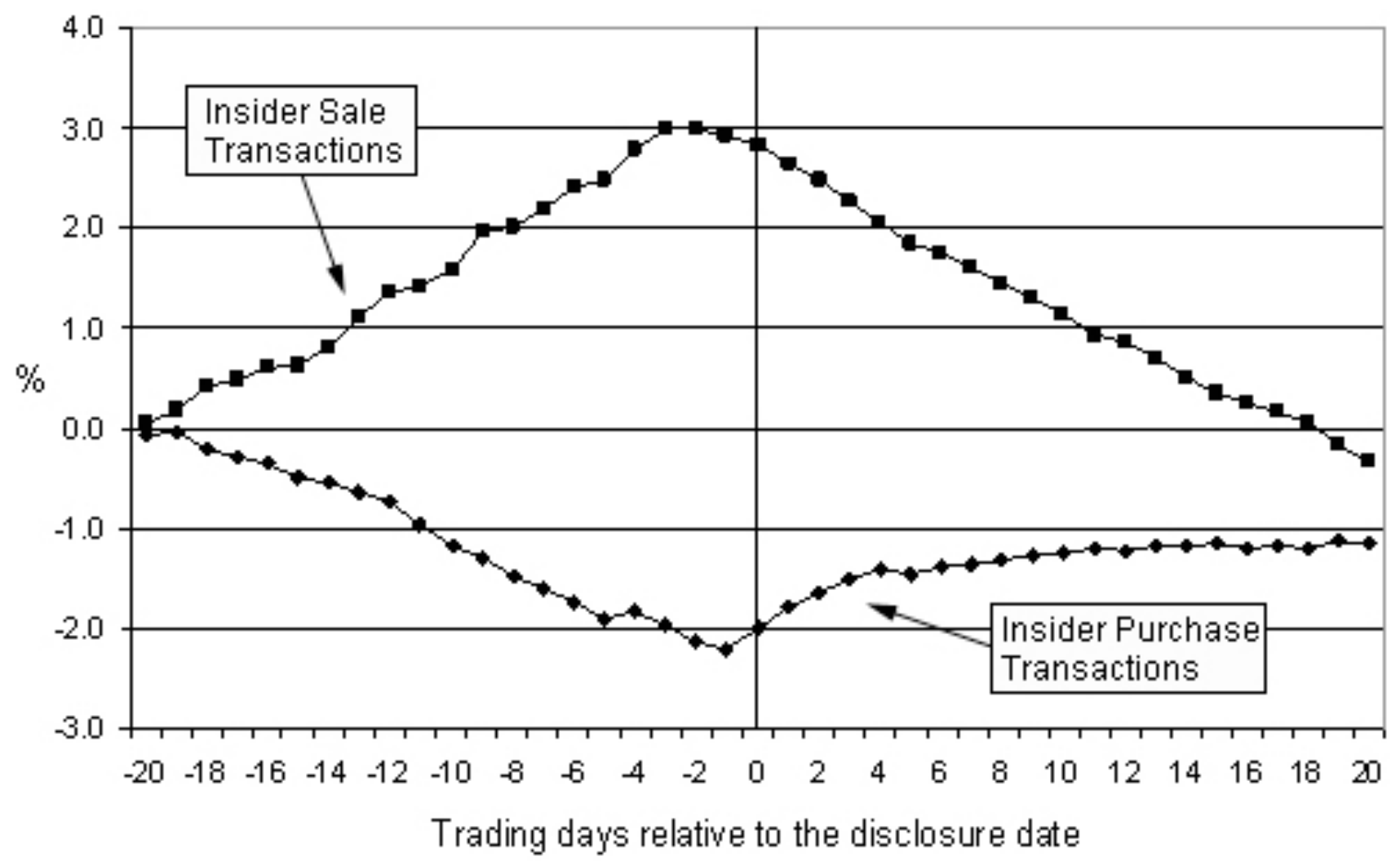

Fig. (2). Abnormal performance of insider trades around the disclosure date. This figure presents average cumulative abnormal returns (CARs) for the total sample of 3,877 insider purchase and 3,855 insider sale transactions (total sample period from July 2002 to December 2007). CARs are calculated in cumulating the abnormal returns of the last 20 trading days before the disclosure day $\left(\mathrm{T}_{-20}\right.$ to $\left.\mathrm{T}_{-1}\right)$, the abnormal return on the disclosure day $\left(\mathrm{T}_{0}\right)$ and the 20 trading days after the disclosure day $\left(\mathrm{T}_{1}\right.$ to $\left.\mathrm{T}_{20}\right)$.

size and power is challenged both by the Wilcoxon test and the proportion test. Fig. (2) presents graphically the CAR development from $\mathrm{T}_{-20}$ to $\mathrm{T}_{+20}$ for insider sales and insider purchase transactions.

\subsection{Abnormal Returns vs Realized Returns}

Following recent research done by Jiang and Zaman [19] we also decompose abnormal returns and calculate in addition cumulative realized returns. Panel A of Fig. (3) shows that the market tends to significantly increase after insider purchase transactions. This indicates that insiders not only reveal pricing relevant information but that they also seem to time their purchase deals.

Furthermore, Panel B of Fig. (3) indicates that insiders tend to sell shares of their company after a general market increase. But in contrast to abnormal returns, average realized returns do not decline after insider sale transactions, which is in line with the lawsuit avoidance hypothesis. Instead the market still increases after sale transactions resulting in a negative abnormal performance for our sample of insider sale deals. The result of this decomposition therefore indicates that insiders both time the market and reduce informational asymmetry between insiders and other market participants.

\subsection{Transaction Size}

To account for the effects of transaction volume we form purchase (sale) sub-samples according to the median of overall purchase (sale) transaction volume. We have 2,016 large purchase transactions in 345 companies and 1,944 large sale transactions in 315 companies (see Panel A of Table 4). For large purchase transactions we find nonsignificant average CARs of $-0.61 \%(-0.28 \%)$ for $\mathrm{T}_{-20}-\mathrm{T}_{-1}$ $\left(\mathrm{T}_{-10}-\mathrm{T}_{-1}\right)$ and significant CARs of $+0.90 \%(+1.02 \%)$ for $\mathrm{T}_{0}$ - $\mathrm{T}_{10}\left(\mathrm{~T}_{0}-\mathrm{T}_{20}\right)$. For large sale transactions we find CARs of $+1.96 \%(+1.05 \%)$ for $\mathrm{T}_{-20}-\mathrm{T}_{-1}\left(\mathrm{~T}_{-10}-\mathrm{T}_{-1}\right)$ and statistically significant CARs of $-1.66 \%(-3.22 \%)$ for $\mathrm{T}_{0}-\mathrm{T}_{10}\left(\mathrm{~T}_{0}-\mathrm{T}_{20}\right)$.

The small transaction volume sub-sample consists of 1,861 (1,941) small purchase (sale) transactions in 320 (285) companies (see Panel B of Table 4). For small purchase transactions we find CARs of $-3.94 \%(-2.27 \%)$ for $\mathrm{T}_{-20}-\mathrm{T}_{-1}$ $\left(\mathrm{T}_{-10}-\mathrm{T}_{-1}\right)$ and CARs of $+0.58 \%(+0.68 \%)$ for $\mathrm{T}_{0}-\mathrm{T}_{10}\left(\mathrm{~T}_{0}-\right.$ $\mathrm{T}_{20}$ ). For small sale transactions we find CARs of $+3.43 \%$ $(+2.27 \%)$ for $\mathrm{T}_{-20}-\mathrm{T}_{-1}\left(\mathrm{~T}_{-10}-\mathrm{T}_{-1}\right)$ and statistically significant CARs of $-2.27 \%(-4.34 \%)$ for $\mathrm{T}_{0}-\mathrm{T}_{10}\left(\mathrm{~T}_{0}-\mathrm{T}_{20}\right)$. Fig. (4) indicates that the timing effect of insiders documented in Figs. (2) and (3) for the total sample is mainly caused by small insider transactions. 
Panel A: Cumulative Realized Returns (CRRs) vs Cumulative Abnormal Returns (CARs) of insider purchase transactions

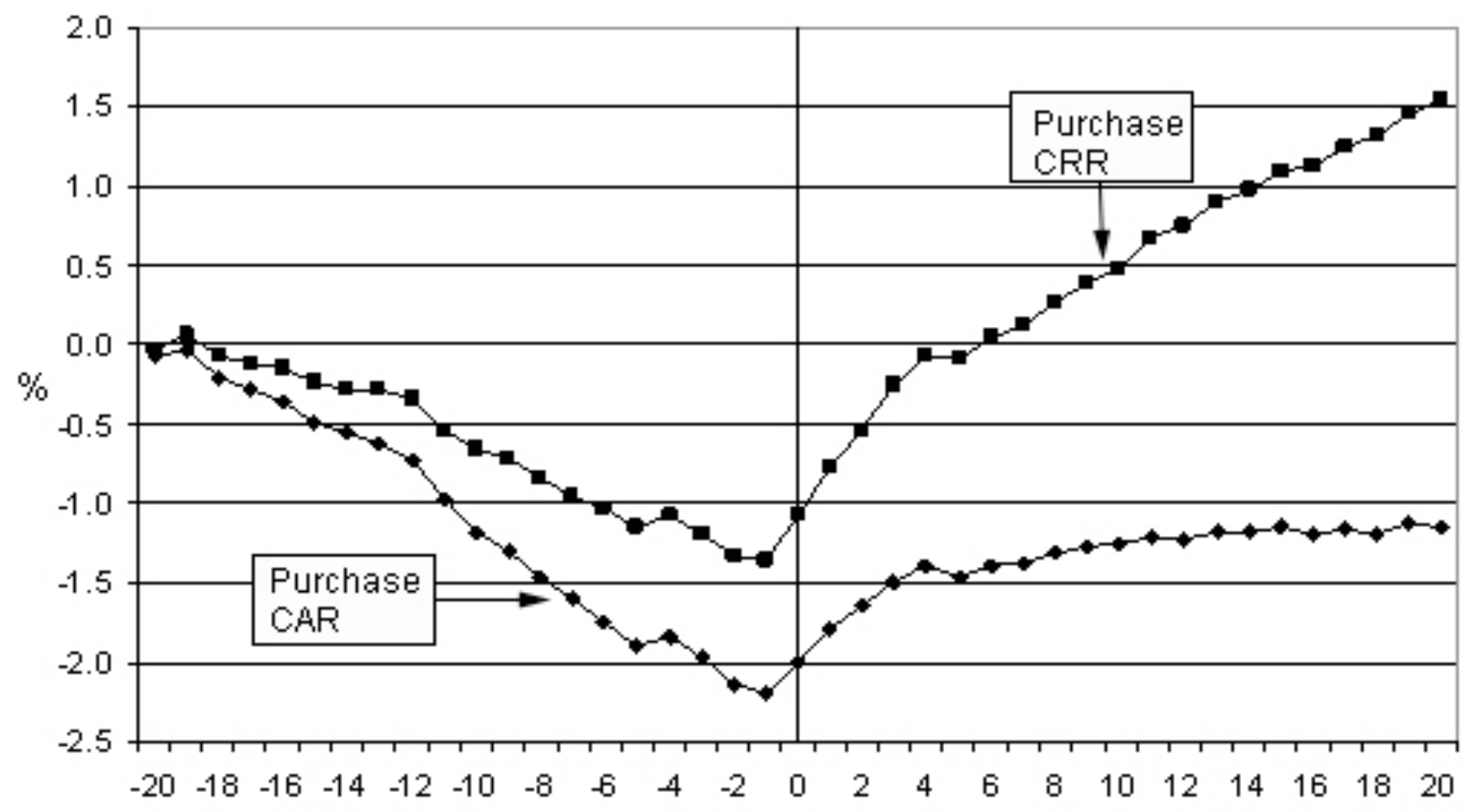

Trading days relative to the disclosure date

Panel B: CRR vs CAR of insider sale transactions

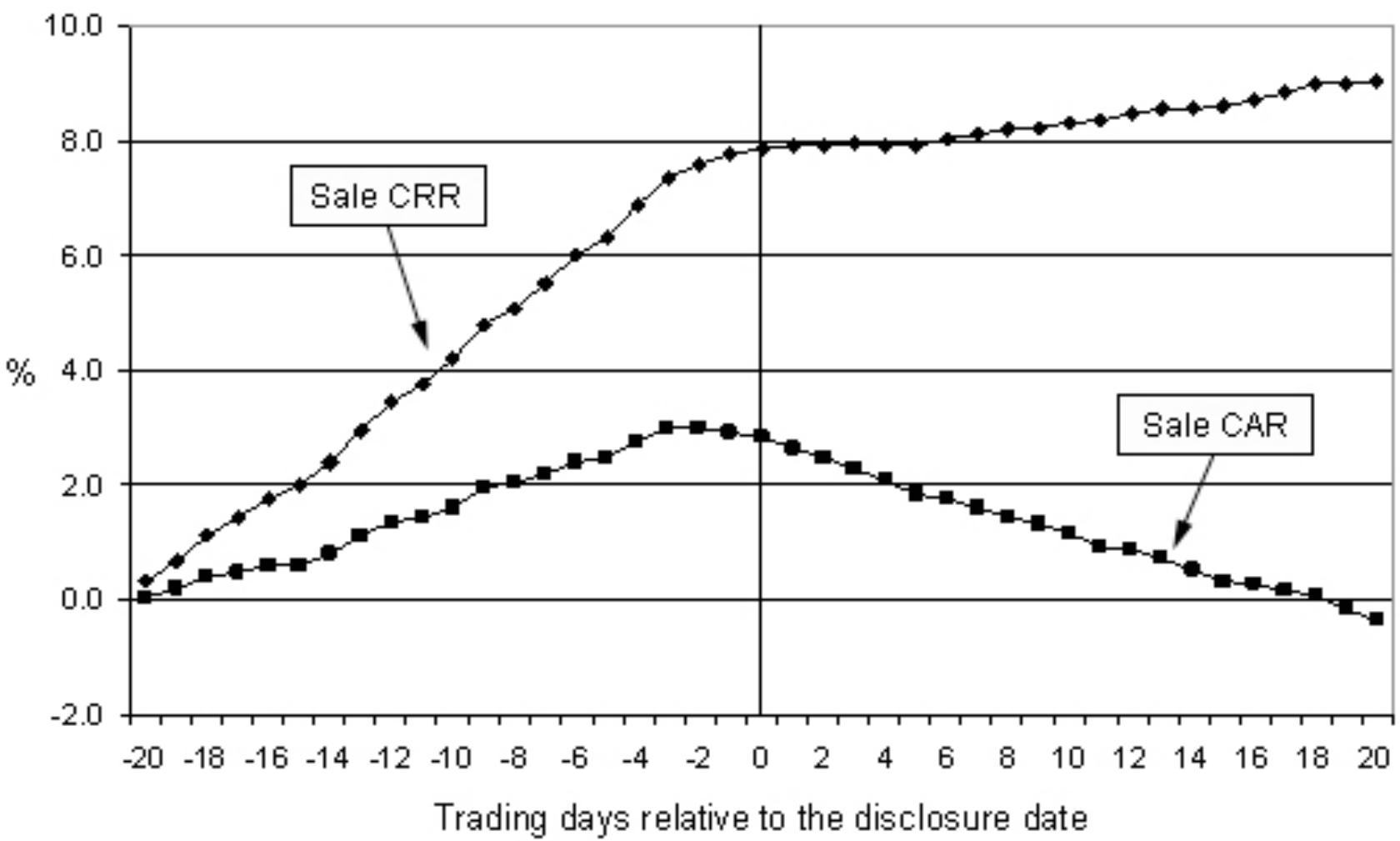

Fig. (3). Abnormal vs raw performance of insider trades. This figure opposes the average cumulative abnormal returns (CARs) to the average cumulative realized returns (CRR) of purchase transactions (Panel A) and sale transactions (Panel B) over the entire sample period from July 2002 to December 2007. CARs (CRRs) are calculated in cumulating the abnormal returns (realized returns) of the last 20 trading days before the disclosure day $\left(\mathrm{T}_{-20}\right.$ to $\left.\mathrm{T}_{-1}\right)$, the abnormal return (realized return) on the disclosure day $\left(\mathrm{T}_{0}\right)$ and the 20 trading days after the disclosure day $\left(\mathrm{T}_{1}\right.$ to $\left.\mathrm{T}_{20}\right)$. 
Table 4. Transactions Size and Abnormal Performance of Insider Transactions

Panel A: Large Insider Transactions

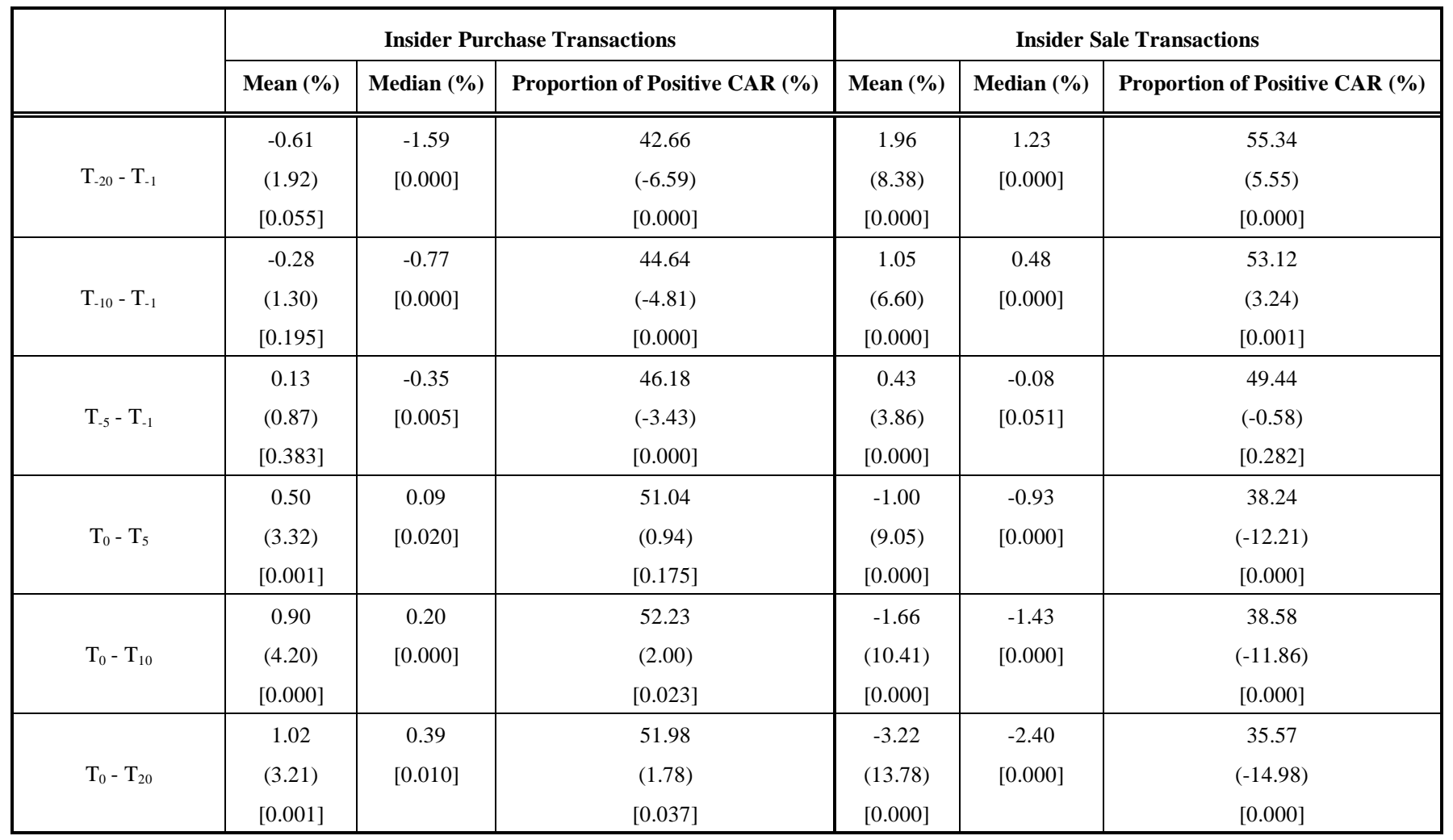

Panel B: Small Insider Transactions

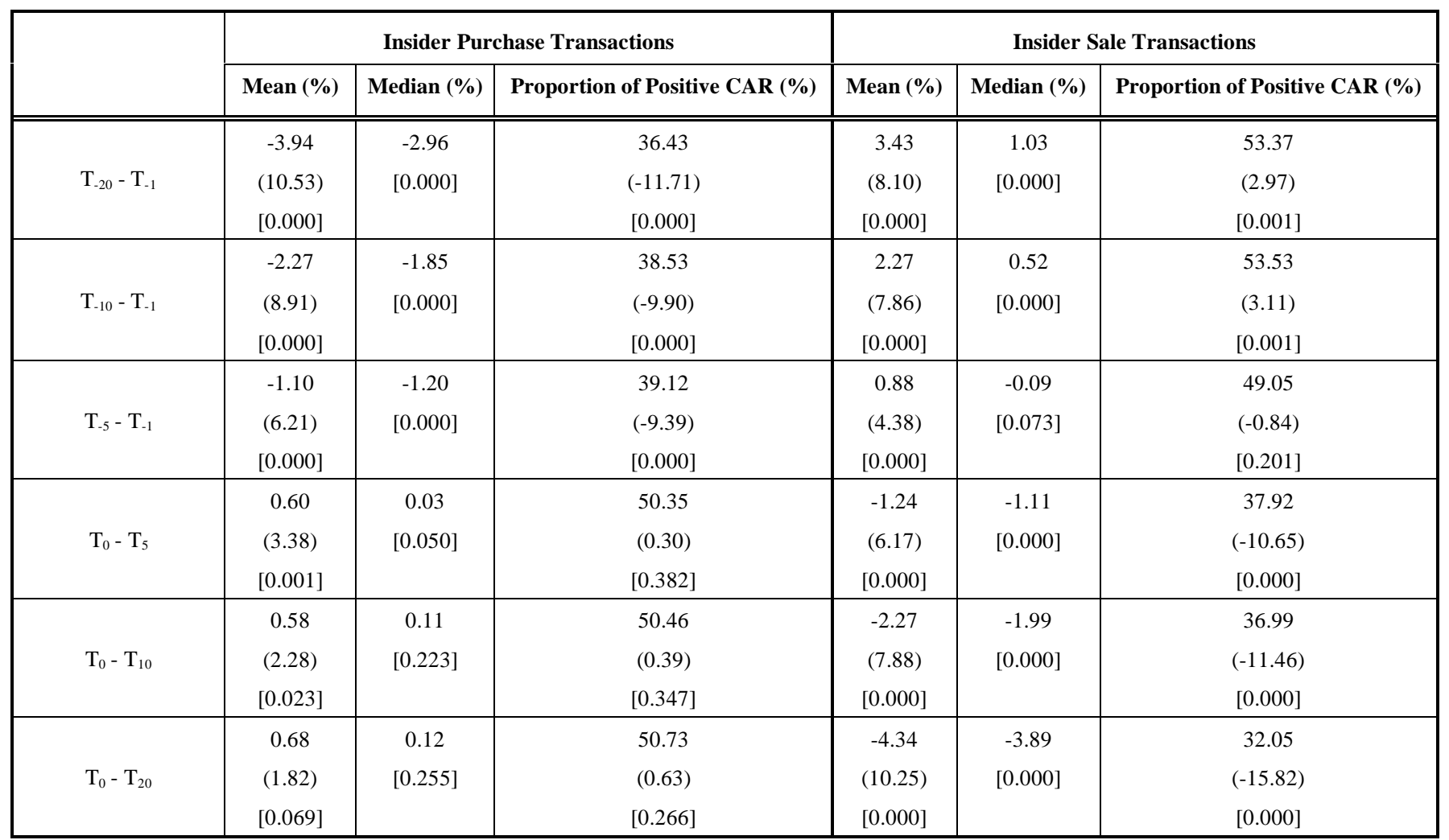

Mean and median cumulative abnormal returns (CARs) and the proportion of positive CARs of large (Panel A) and small (Panel B) insider purchase and sale transactions over the entire sample period from July 2002 until December 2007. Test statistics are given in brackets () and p-values within []. 
Panel A: Large insider transactions

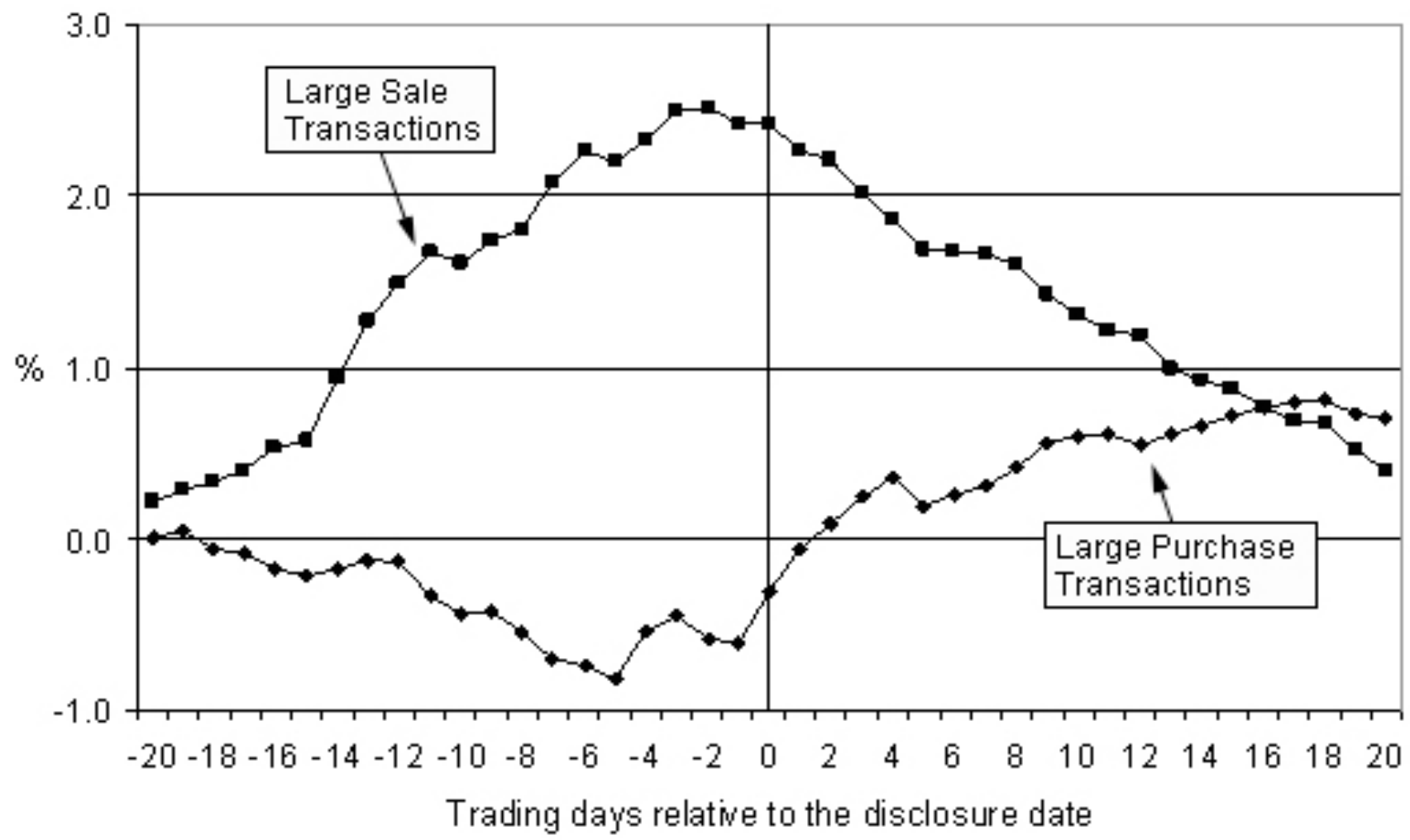

Panel B: Small insider transactions

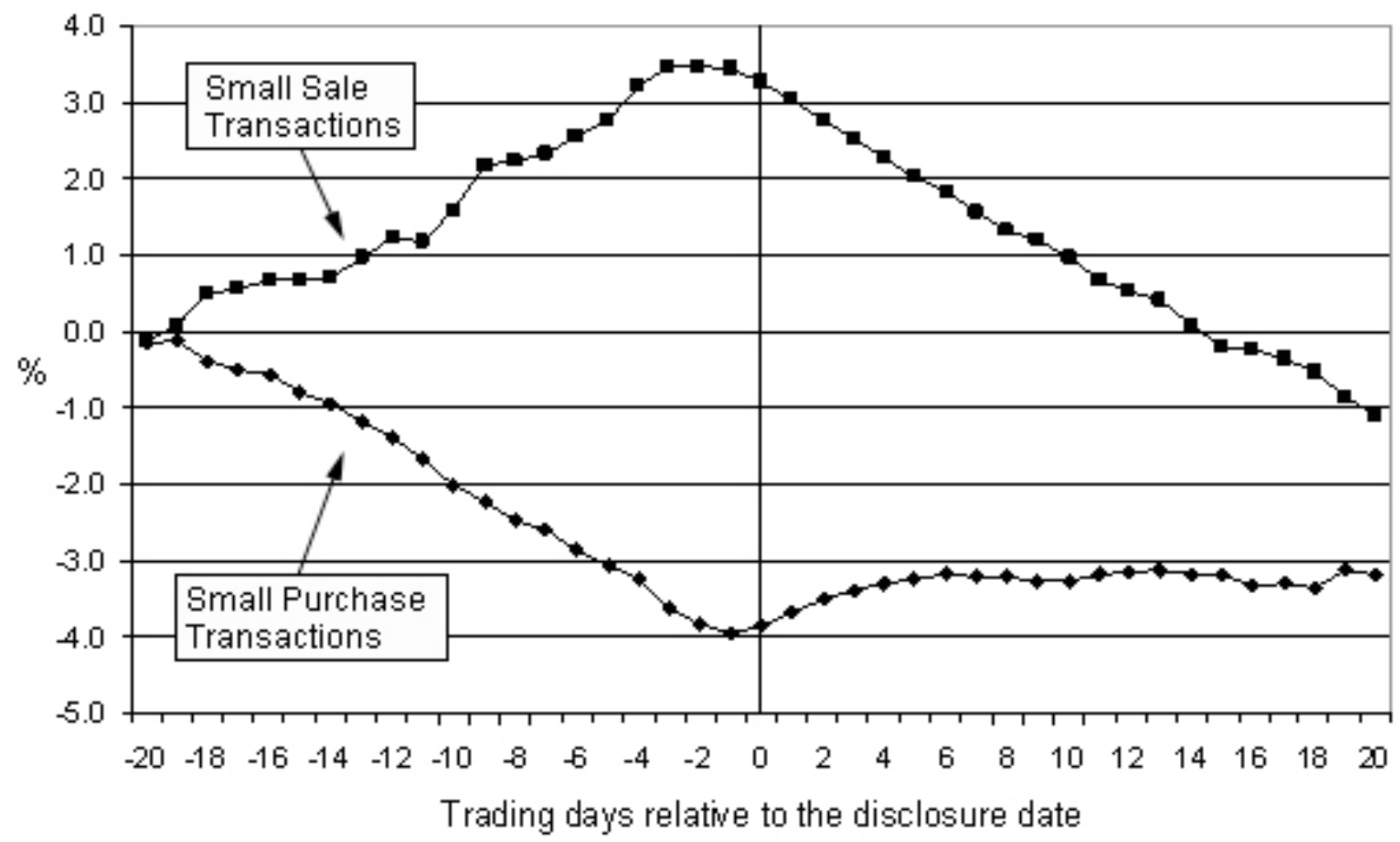

Fig. (4). Transactions size and abnormal performance of insider transactions. This figure presents average cumulative abnormal returns (CARs) for large (Panel A) and small (Panel B) insider purchase and sale transactions. Large and small insider purchase and sale transactions are calculated with respect to the median of overall transaction volume of insider purchases and sales, respectively. CARs are calculated in cumulating the abnormal returns of the last 20 trading days before the disclosure day $\left(\mathrm{T}_{-20}\right.$ to $\mathrm{T}_{-1}$ ), the abnormal return on the disclosure day $\left(\mathrm{T}_{0}\right)$ and the 20 trading days after the disclosure day $\left(\mathrm{T}_{1}\right.$ to $\left.\mathrm{T}_{20}\right)$. 


\subsection{Firm Size}

One expects larger companies to have a more efficient information policy than smaller companies. Large companies are more heavily followed by financial analysts and have a larger fraction of institutional stockholders - facts that typically reduce information asymmetries. This expectation is confirmed by our findings. Insider trading activity is substantial in large companies. For large companies we have 2,462 insider purchases in 271 companies and 2,696 insider sales in 266 companies whereas in small companies we have
1,351 insider purchases in 204 companies and 1,143 insider sales in 171 companies.

For purchase transactions by corporate insiders in large companies we find significant CARs of $-2.80 \%(-1.53 \%)$ for $\mathrm{T}_{-20}-\mathrm{T}_{-1}\left(\mathrm{~T}_{-10}-\mathrm{T}_{-1}\right)$ and insignificant CARs of $+0.15 \%(-0.31$ $\%)$ for $\mathrm{T}_{0}-\mathrm{T}_{10}\left(\mathrm{~T}_{0}-\mathrm{T}_{20}\right)$. For the corresponding sale transactions our results reveal significant CARs of $+1.96 \%(+1.05$ $\%)$ for $\mathrm{T}_{-20}-\mathrm{T}_{-1}\left(\mathrm{~T}_{-10}-\mathrm{T}_{-1}\right)$ and significant CARs of $-1.66 \%(-$ $3.22 \%$ ) for $\mathrm{T}_{0}-\mathrm{T}_{10}\left(\mathrm{~T}_{0}-\mathrm{T}_{20}\right)$ (see Panel $\mathbf{A}$ of Table $\left.\mathbf{5}\right)$.

Table 5. Company Size and Abnormal Performance of Insider Transactions

Panel A: Insider Transactions in Large Companies

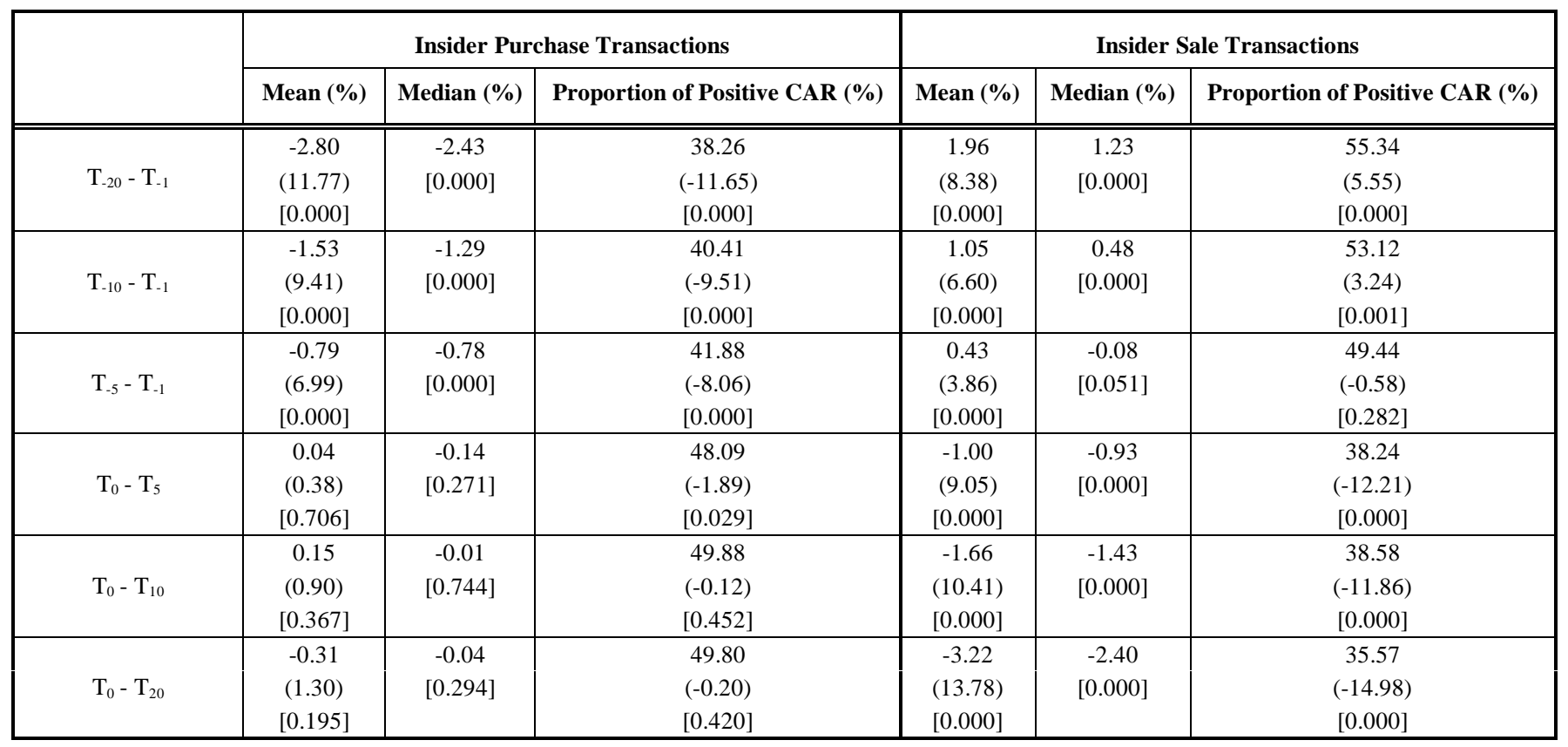

Panel B: Insider Transactions in Small Companies

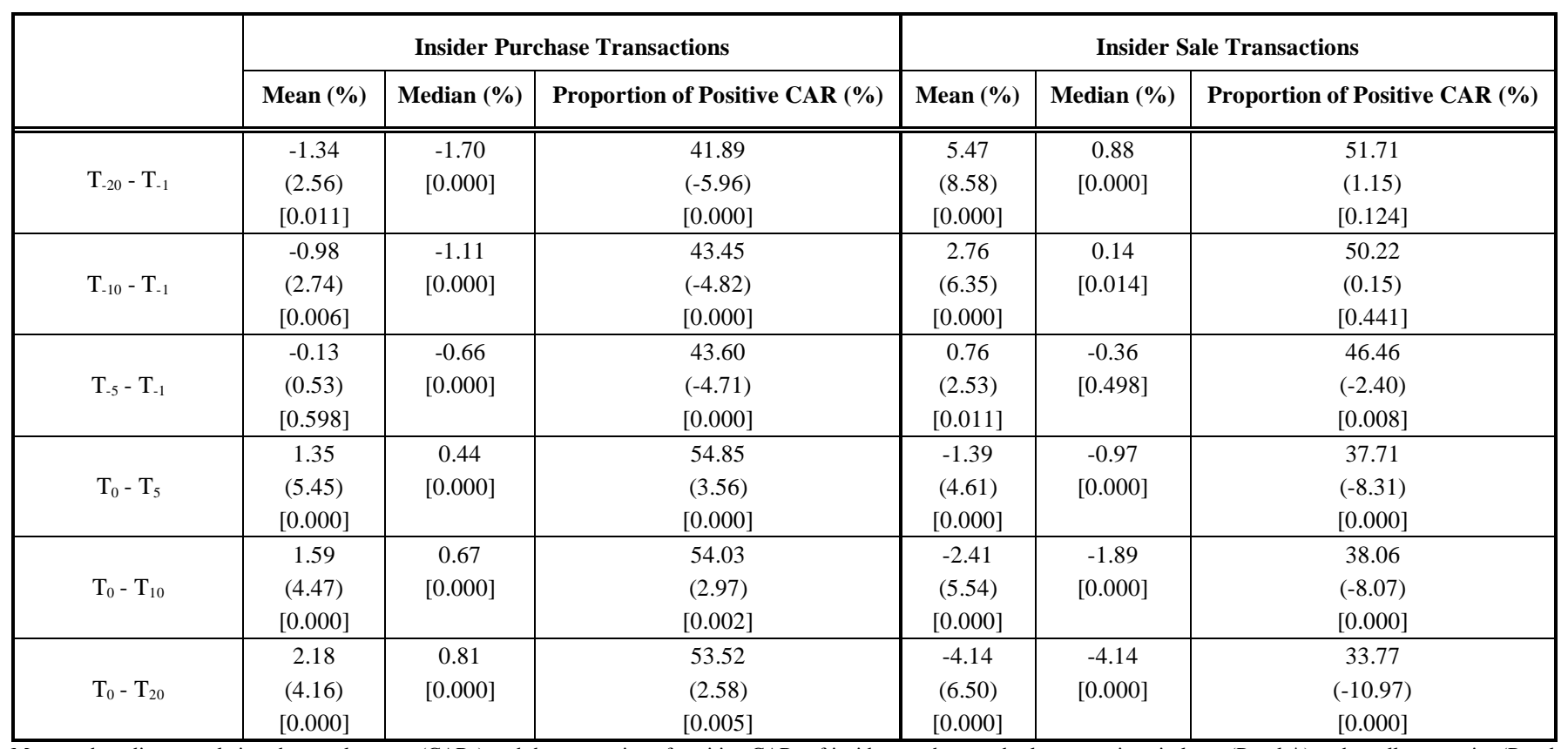

Mean and median cumulative abnormal returns (CARs) and the proportion of positive CARs of insider purchase and sale transactions in large (Panel A) and small companies (Panel B) over the entire sample period from July 2002 until December 2007. Test statistics are given in brackets () and p-values within []. 
Panel A: Insider trading in large companies

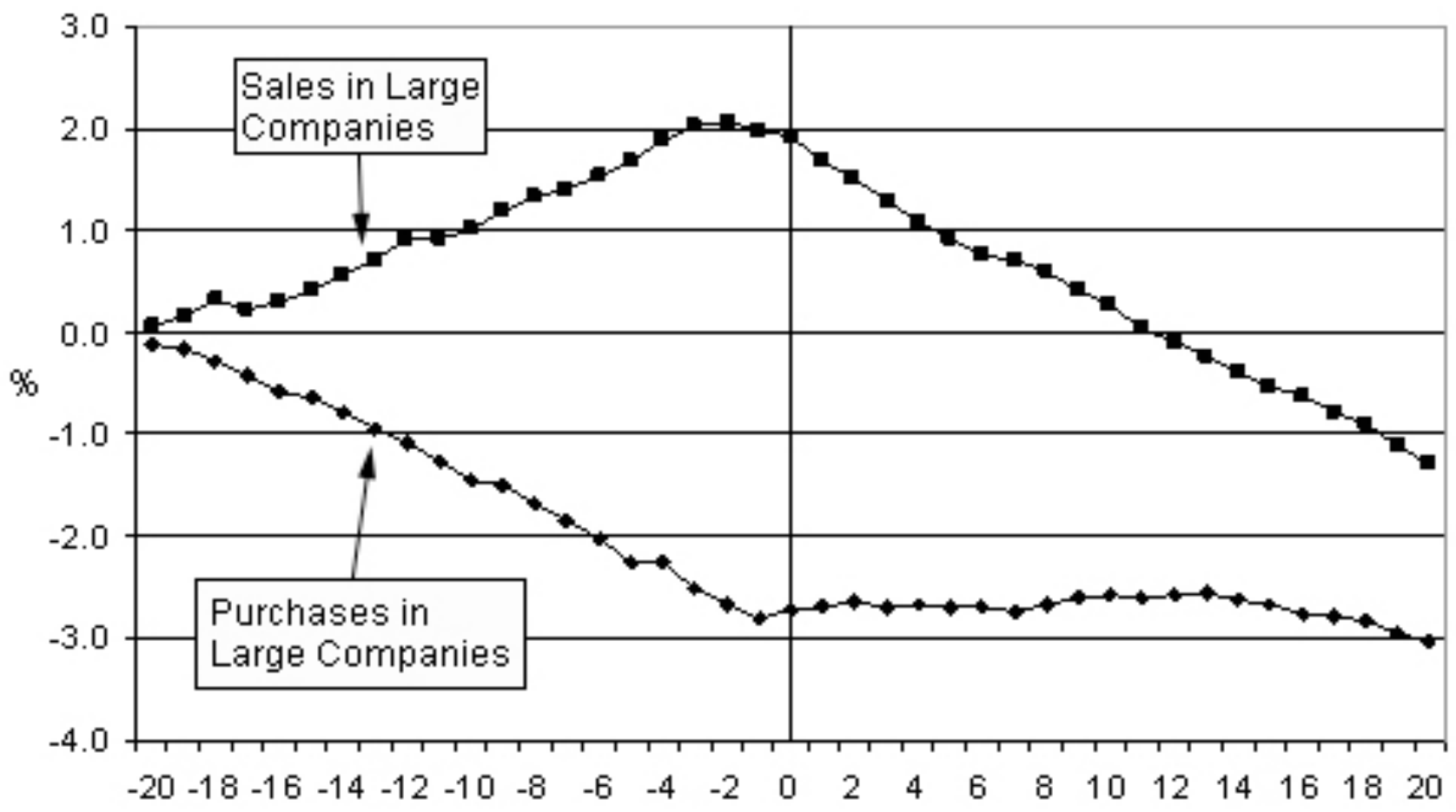

Trading days relative to the disc losure date

Panel B: Insider trading in small companies

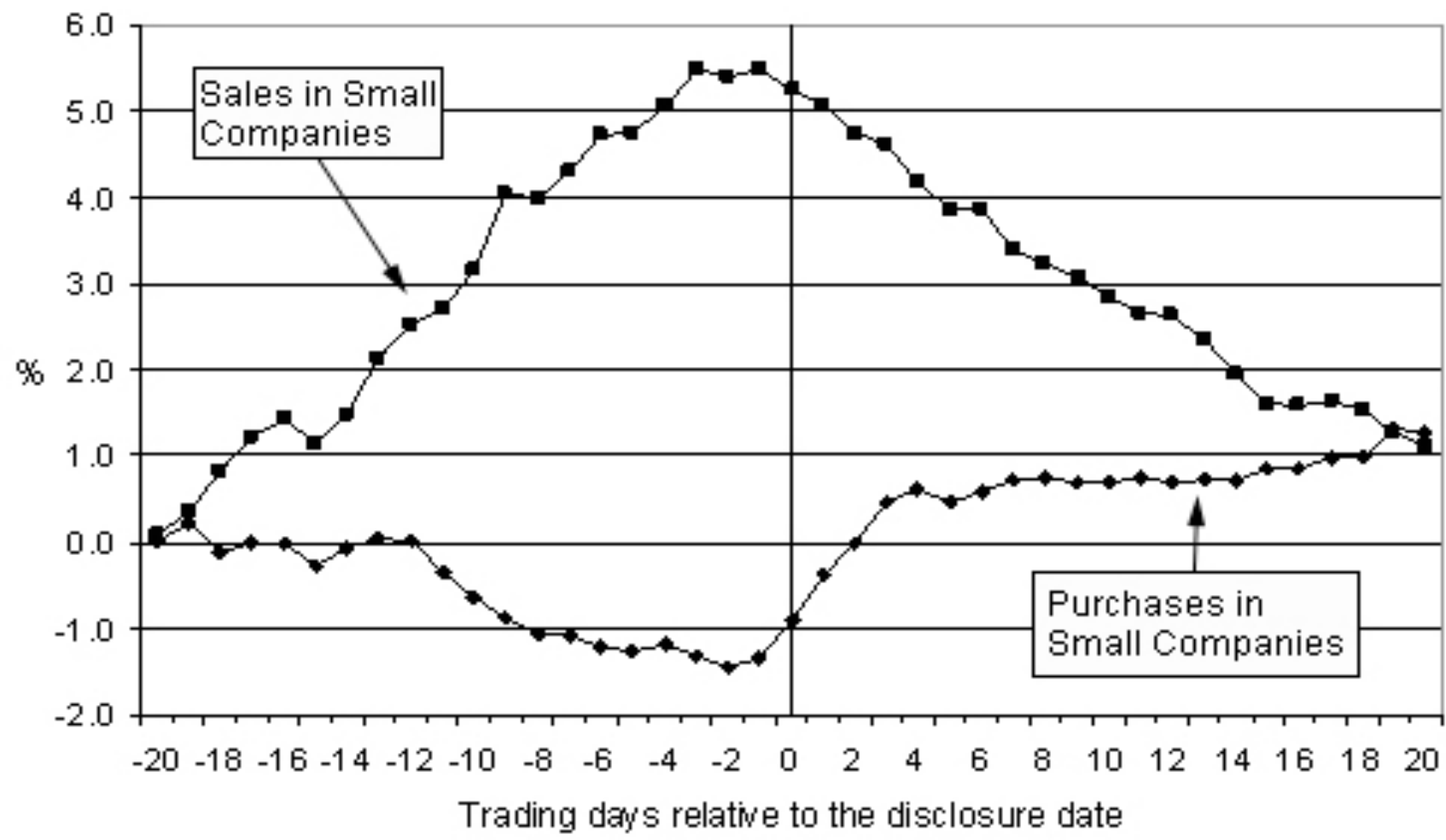

Fig. (5). Company size and abnormal performance of insider transactions. This figure presents average cumulative abnormal returns (CARs) for insider purchase and sale transactions in large (Panel A) and in small companies (Panel B). To distinguish between large and small companies we calculate the market value of every company on the first trading day in every year of the sample period. Then we compute the median market value for every year. Insider trading in large and small companies is defined with respect to the median market value in the year the insider transaction took place. CARs are calculated in cumulating the abnormal returns of the last 20 trading days before the disclosure day $\left(\mathrm{T}_{-20}\right.$ to $\left.\mathrm{T}_{-1}\right)$, the abnormal return on the disclosure day $\left(\mathrm{T}_{0}\right)$ and the 20 trading days after the disclosure day $\left(\mathrm{T}_{1}\right.$ to $\left.\mathrm{T}_{20}\right)$. 
For purchase transactions by corporate insiders in small companies we find significant CARs of $-1.34 \%(-0.98 \%)$ for $\mathrm{T}_{-20}-\mathrm{T}_{-1}\left(\mathrm{~T}_{-10}-\mathrm{T}_{-1}\right)$ and significant CARs of $+1.59 \%$ $(+2.18 \%)$ for $\mathrm{T}_{0}-\mathrm{T}_{10}\left(\mathrm{~T}_{0}-\mathrm{T}_{20}\right)$. For the corresponding sale transactions we can document significant CARs of $+5.47 \%$ $(+2.76 \%)$ for $\mathrm{T}_{-20}-\mathrm{T}_{-1}\left(\mathrm{~T}_{-10}-\mathrm{T}_{-1}\right)$ and significant CARs of $2.41 \%(-4.14 \%)$ for $\mathrm{T}_{0}-\mathrm{T}_{10}\left(\mathrm{~T}_{0}-\mathrm{T}_{20}\right)$ (see Panel $\mathbf{B}$ of Table 5). Fig. (5) also documents graphically that selling transactions of insiders in small companies are much more informative than those in large companies.

\section{CONCLUSION}

We assess the efficiency of corporate information policy by looking at market reactions to disclosures of insider trading. Our research focuses on insider trading announcements for all German traded companies in the period July 2002 to December 2007. Consistent with prior efforts we document contrarian investment strategies among insider transactions.

We find strong evidence of market reaction to insider sales, but there is no or only a modest market reaction to insider purchases, a somewhat astonishing result. Research on insider trading in the U.S. suggests that insiders are much more cautious at sale transactions and abstain to make use of their private information advantage in sale transactions. The reason for this behavior lies most probably in the increased litigation risk associated with insider sales. The absence of class-action lawsuits in German legislation might explain our findings of a significant negative abnormal performance after the disclosure date. Another explanation for this observation might be that in insider sale transactions only abnormal returns are negative whereas cumulative raw returns (not adjusted for market movements) do not decrease after the disclosure date.

A further interesting finding of our research is that insider purchase transactions in small companies convey more information for outsiders than in large companies. We conclude that information policy is more efficient in larger companies than in smaller ones. We also document that large volume insider trades reveal more private information than small volume trades do.

\section{ACKNOWLEDGEMENTS}

We would like to thank two anonymous referees and seminar participants at the Vienna University of Technology for helpful comments and suggestions. We also thank Reuters GesmbH Vienna for providing data.

\section{REFERENCES}

[1] Jaffe JF. Special information and insider trading. J Bus 1974; 47: 410-28.

[2] Finnerty JE. Insiders and market efficiency. J Finance 1976; 31: 1141-8.

[3] Seyhun NH. Insiders' profits, costs of trading, and market efficiency. J Financ Econ 1986; 16: 189-212.

[4] Lakonishok J, Lee I. Are insider trades informative? Rev Financ Stud 2001; 14: 79-111.
[5] Jeng LA, Metrick A, Zeckhauser RJ. Estimating the returns to insider trading: A performance-evaluation perspective. Rev Econ Stat 2003; 85: 453-71.

[6] Aktas N, de Bodt E, Van Oppens H. Legal insider trading and market efficiency. J Bank Finance 2008; 32: 1379-92.

[7] Pope PF, Morris RC, Peel DA. Insider trading, some evidence on market efficiency and directors' share dealings in Great Britain. J Bus Finance Acc 1990; 17: 359-80.

[8] Gregory A, Matako J, Tonks I, Purkis R. UK directors' dealings: The impact of dealings in smaller firms. Econ J 1994; 104: 37-53.

[9] Calvo EG, Lasfer M. Why do corporate insiders trade? The UK evidence. Working Paper University of Madrid and City University London 2002.

[10] Fidrmuc J, Goergen M, Renneboog L. Insider trading, news releases and ownership concentration. J Finance 2006; 61: 341-72.

[11] Biesta MA, Doeswijk RQ, Donker HA. The profitability of insider trades in the Dutch stock market. Working Paper Erasmus University Rotterdam and Institute for Research and Investment Services. 2003.

[12] Aktas N, de Bodt E, Riachi I, de Smedt J. Legal insider trading and stock market reaction: Evidence from the Netherlands. ECORE Discussion Paper Universite Catholique de Louvain, Universite Lille 2 and Banking, Finance and Insurance Commission 2007.

[13] Del Brio E, de Miguel A, Perote J. An investigation of insider trading profits in the Spanish stock market. Q Rev Econ Finance 2002; 42: 73-94.

[14] Eckbo BE, Smith DC. The conditional performance of insider trades. J Finance 1998; 53: 467-98.

[15] Lorie JH, Niederhoffer V. Predictive and statistical properties of insider trading. J Law Econ 1968; 11: 35-53.

[16] Kose JL, Lang HP. Insider trading around dividend announcements: Theory and evidence. J Finance 1991; 46: 1361-89.

[17] Huddart S, Hughes JS, Levine CB. Public disclosure and dissimulation of insider trades. Econometrica 2001; 69: 665-81.

[18] Piotroski JD, Roulstone DT. The influence of analysts, institutional investors, and insiders on the incorporation of market, industry, and firm-specific information into stock prices. Working Paper University of Chicago 2004.

[19] Jiang X, Zaman MA. Aggregate insider trading and the predictability of market returns: Contrarian strategy or managerial timing? Working Paper University of Northern Iowa 2007.

[20] Wong MCS, Cheung YL, Wu L. Insider Trading in the Hong Kong Stock Market. Asia-Pacific Financ Markets 2002; 7: 275-88.

[21] Heidorn T, Meyer B, Pietrowiak A. Performance-Effekte nach Director's Dealings in Deutschland, Italien und den Niederlanden. Working Paper Frankfurt School of Finance \& Management (HfB) 2004.

[22] Stotz O. Germany's new insider law: The empirical evidence after the first year. Ger Econ Rev 2006; 7: 449-62.

[23] Betzer A, Theissen E. Insider trading and corporate governance: The case of Germany. Working Paper University of Bonn 2007.

[24] Dymke BM, Walter A. Insider trading in Germany - Do corporate insiders exploit inside information? Working Paper University of Tübingen 2007.

[25] Klinge M, Seifert U, Stehle R. Abnormal returns in the vicinity of insider transactions: The case of Germany. Working Paper Roland Berger and Humboldt-University Berlin 2005.

[26] MacKinlay AC. Event studies in economics and finance. J Econ Lit 1997; 35: 13-9.

[27] Ball R, Brown P. An empirical evaluation of accounting income numbers. J Acc Res 1968; 6: 159-78.

[28] Fama E, Fisher L, Jensen M, Roll R. The adjustment of stock prices to new information. Int Econ Rev 1969; 10: 1-21.

[29] Campbell JY, Lo AW, MacKinlay AC. The econometrics of financial markets. Chichester. Princeton University Press 1997.

[30] Serra AP. Event study test: A brief survey. Working Paper Universidade do Porto 2004. 